\title{
Wczesna edukacja dziecka w opiniach opiekunów poznańskich żłobków - raport z badań
}

\begin{abstract}
Abstrakt
Celem opracowania jest ukazanie sposobów postrzegania wczesnej edukacji dziecka przez opiekunów dziecka do lat trzech zatrudnionych w poznańskich żłobkach publicznych. Definiując pojęcie wczesnodziecięcej edukacji, autor zaznacza, że edukacja dziecka do trzeciego roku życia jest edukacją fundamentalną i rozwojową w tym sensie, że wytycza ją potencjał rozwojowy dziecka. Powinna mieć charakter niedyrektywny i opierać się na ustawicznej obserwacji i diagnozie rozwoju dziecka. Wczesna edukacja to organizowanie podopiecznemu sytuacji zadaniowych zgodnych ze strefą najbliższego rozwoju i uważne towarzyszenie dziecku w rozwoju. Zaprezentowane w tekście wyniki badań własnych autorki ukazują szereg trudności w zakresie postrzegania przez opiekunów dziecka do lat trzech edukacji wczesnodziecięcej, pozwalają jednak na wysnucie wniosku, że opiekunki są świadome faktu, że w zakres oddziaływań wobec dziecka do trzeciego roku życia powinny także włączyć sposoby oddziaływań edukacyjnych.
\end{abstract}

Słowa kluczowe: dziecko, edukacja wczesnodziecięca, żłobek.

\section{Early child education in the opinions of caregivers of Poznan crèches - research report}

\begin{abstract}
The aim of the study is to show the perception of early childhood education on the part of caregivers working in crèches in Poznan and taking care of children up to three years of age. Defining the concept of early childhood education, the author emphasizes that education of a child up to the age of three is fundamental and developmental in the sense that it is determined by the developmental potential of a child. It should be non-directive and based on continuous observation and diagnosis
\end{abstract}

\footnotetext{
* Uniwersytet im. Adama Mickiewicza w Poznaniu, Wydział Studiów Edukacyjnych, Zakład Edukacji Elementarnej i Terapii Pedagogicznej.
} 
of child development. Early education means organizing task-oriented situations in accordance with the nearest development zone and closely accompanying the child in the development. The results of the study conducted by the author and presented in this text reveal a number of difficulties in terms of perception of early childhood education on the part of caregivers of children up to three years old. Nevertheless, they allow to draw a conclusion that the caregivers are aware of the fact that the scope of influencing children under three years of age should also include ways of educational impact.

Keywords: child, early childhood education, crèche.

\section{Edukacja wczesnodziecięca - wprowadzenie}

Stereotypowo postrzegana przez polskie społeczeństwo edukacja ma miejsce wówczas, gdy opiekun, nauczyciel, wychowawca, korepetytor czy instruktor dyktuje sposób pracy z dzieckiem. Dziecko ma się nauczyć tego, co zostało zaprezentowane przez dorosłego, ma przyswoić sobie wiedzę, ma „umieć”: mówić w języku obcym, „umieć” pływać, „umieć” zatańczyć - chciałoby się ironicznie rzec - jak mu zagrają. Ten stereotyp obserwować można przez pryzmat tendencji do zapisywania dzieci na zajęcia dodatkowe, do dbałości rodzica o zapełnienie dziecięcym pismem wszystkich kart pracy, jakie obowiązują w danym roku szkolnym, do rozliczania ucznia z tego, czego się nauczył w drodze testów, a w przypadku najmłodszych dzieci - tendencji do wybierania zabawek edukacyjnych, które „mówią” po angielsku, „nazywają” literki, „świecą”, gdy dziecko dotknie palcem tego, co należy dotknąć.

Wszystkie wskazane powyżej sytuacje pomijają istotę kształcenia się człowieka - jego doświadczanie nie tylko sukcesów, ale i porażek, doświadczanie dialogu z innymi ludźmi, obserwację zjawisk, ludzi, sytuacji, samodzielne wnioskowanie i doskonalenie nabytych umiejętności. Społeczne postrzeganie edukacji przywodzi na myśl ławki, szkołę, jednostkę czasową, zaplanowaną lekcję lub zajęcia, instrukcję, tzw. „dyscyplinę”, dyrektywność. Edukacja we współczesnym świecie jest instrumentalizowana, staje się towarem, za który rodzice chętnie płacą $\mathrm{w}$ trosce o lepszą przyszłość swoich dzieci. We współczesnym świecie, „dziecko staje się nie tylko obiektem troski rodzicielskiej, ale i przyczyną rodzinnych wydatków, inwestycją” (Segiet 2014: 24). Rodzice „tworzą dzieciństwo na miarę swoich oczekiwań, a nie na miarę oczekiwań dziecka, które musi sprostać wymaganiom jakże często niewyrozumiałego rodzica, sytuującego go w trudnych niejednokrotnie dla niego sytuacjach" (tamże). Tego samego rodzaju edukacji oczekuje się niejednokrotnie we współczesnym żłobku, w kontekście wspierania rozwoju dziecka w wieku poniemowlęcym. 
O edukacji dziecka w okresie wczesnego dzieciństwa czytamy we wprowadzonej w dniu 4 lutego 2011 r. ustawie o opiece nad dziećmi w wieku do lat $3^{1}$. Ustawa określa zasady organizowania i funkcjonowania opieki nad dziećmi w wieku do lat 3, warunki świadczonych usług, kwalifikacje osób sprawujących opiekę, zasady finansowania opieki i nadzór nad warunkami i jakością sprawowanej opieki, nie definiuje jednak wczesnodziecięcej edukacji². Ramy edukacji dziecka do lat trzech nie zostają określone także przez konkretne rozporządzenie, edukacja taka zatem realizowana jest najczęściej zgodnie ze stereotypem „zajęć”.

Jeżeli jednak przyjmiemy, że wobec dziecka do trzeciego roku życia należy podejmować oddziaływania o charakterze edukacyjnym, należy zmienić sposób myślenia o edukacji. W centrum wczesnodziecięcej edukacji jest dziecko i jego potencjał rozwojowy - to jedyny właściwy punkt wyjścia do zrozumienia zakresu pojęcia wczesnej, propedeutycznej edukacji dziecka do trzeciego roku życia 3 .

Edukacja dziecka do trzeciego roku życia jest edukacją fundamentalną i rozwojową w tym sensie, że wytycza ją potencjał rozwojowy dziecka. Idąc tropem Anny Brzezińskiej, na potrzeby stworzenia definicji wczesnodziecięcej edukacji (dla dziecka w wieku do lat trzech) przyjąć można, że „wczesna edukacja to wspieranie rozwoju dziecka poprzez tworzenie okoliczności sprzyjających gromadzeniu wiedzy i nabywaniu umiejętności w sposób naturalny i spontaniczny w różnych sytuacjach, w których dziecko się znajduje" (Kram, Mielcarek 2014: 8).

Wczesnodziecięca edukacja powinna mieć charakter niedyrektywny i opierać się na ustawicznej obserwacji i diagnozie rozwoju dziecka. Edukacja taka nie odwołuje się do założeń dydaktyki, nie można w jej przypadku mówić o realizacji zajęć, sporządzaniu gotowych scenariuszy czy planów pracy i ich konsekwentnym realizowaniu, bowiem to małe dziecko wytycza sposób oddziaływań opiekuna. Jest to kształcenie (się) dziecka w sytuacjach naturalnych (tamże), przede wszystkim w kontakcie ze światem, z dorosłymi (lub też bardziej doświadczonymi dziećmi, np. w kontakcie ze starszym rodzeństwem), których dziecko obserwuje i naśladuje.

\footnotetext{
1 Dz.U. 2011, nr 45, poz. 235.

2 Należy zaznaczyć, że wśród funkcji żłobków w tzw. ustawie żłobkowej wymienia się funkcję opiekuńczą, wychowawczą i edukacyjną, co dodatkowo wprowadza pewien element chaosu pojęciowego i nie sprzyja jednolitemu rozumieniu edukacji małego dziecka. Wydaje się, że wprowadzenie pojęcia „edukacja” do ustawy nie zostało należycie przemyślane, a praktyka ukazuje, że opiekunowie i rodzice dzieci w związku z założeniami ustawy wyraźnie oddzielają wychowanie od edukacji, dopatrując się edukacji wyłącznie tam, gdzie organizowane są określone tematem, miarą czasu, opisane konkretnym scenariuszem i realizowane przez tzw. „specjalistę” zajęcia edukacyjne. Powoduje to dodatkowo społeczne błędne przekonanie, że opiekunka w żłobku zajmuje się wyłącznie opieką, zaś do organizowania edukacji należy dodatkowo zatrudnić nauczyciela lub instruktora (wniosek poczyniony został w oparciu o kilkuletnie doświadczenie autorki tekstu, która uczestniczyła w kolejnych edycjach konkursu ofert żłobków niepublicznych w Poznaniu, wynika ponadto z doświadczenia zawodowego oraz wywiadów realizowanych zarówno z rodzicami, jak i pracownikami poznańskich żłobków publicznych oraz niepublicznych).

3 Więcej na temat założeń wczesnodziecięcej edukacji dziecka autorka pisze w publikacjach z lat 20142017, a także w opracowywanej obecnie książce na temat: Wczesnodziecięca edukacja w żłobku (publikacja wydana zostanie w 2018 r. przez Wydawnictwo Naukowe UAM).
} 
Wczesna edukacja powinna się zatem koncentrować na poszanowaniu potencjału dziecka, na wprowadzaniu go „w zakres pierwszych norm, szczególnie związanych ze zdrowiem i ruchem w przestrzeni ku przedmiotom i ku znanym osobom" (Kupisiewicz 2010: 134).

Niezbędnym warunkiem efektywnego poznawania świata przez dziecko jest odejście dorosłego od nakazów. Koncepcję taką promowała Emmi Pikler, Magda Gerber czy Caroline Pratt (por. Hammond 2009; Gerber 1979). C. Pratt rozwinęła filozofię wewnętrznej motywacji pozbawionej „działań o charakterze formalnym, zorientowanych na nauczyciela i pasywnych, któremu towarzyszyłby pasywny odbiór przez dzieci" (por. Arnold 2009: 26). W procesie poznawania świata, według wspomnianych autorek, panuje zasada „wolnego wyboru”, która wydaje się być istotną dla tworzenia dziecku warunków prorozwojowych w sytuacjach naturalnych.

Wczesna edukacja to organizowanie wychowankowi sytuacji zadaniowych zgodnych ze sferą najbliższego rozwoju i uważne towarzyszenie dziecku w rozwoju. Warto także podkreślić, że w związku z założeniami wczesnodziecięcej edukacji prezentowanymi przez zespół A. Brzezińskiej, kluczowymi kompetencjami w procesie rozwoju dziecka w wieku niemowlęcym i poniemowlęcym są: lokomocja, manipulacja oraz komunikacja (por. Kram, Mielcarek 2014). Te kompetencje powinny wytyczać cele wczesnodziecięcej edukacji w żłobku.

Edukacja dziecka do lat trzech powinna przywodzić na myśl koncepcję Adolfa Ferriere'a, który uważał, że: „na dziecko nie należy działać, lecz pobudzać je do działania..., prawdziwa praca to aktywność spontaniczna i inteligentna, która pochodzi z wewnątrz, rozwija się i przejawia na zewnątrz" (Kupisiewicz 2010: 134). Cytowane tu słowa wpisują się także w koncepcję towarzyszenia w rozwoju. Ewa Marynowicz-Hetka (Marynowicz-Hetka 2009: 135-138) opisuje tę koncepcję jako koncepcję „towarzyszenia w rozwoju dziecku i jego rodzinie w kontekście kompetencji profesjonalnego wychowawcy. Podkreśla takie jego cechy, jak wiedza o dziecku i środowisku jego życia - rodzinnym i instytucjonalnym, umiejętność refleksji nad praktyką, twórczość, umiejętności metodyczne bycia z drugim człowiekiem. Zasadniczym jednak elementem towarzyszenia w rozwoju dziecku staje się umiejętność wychowawcy polegająca na byciu «Obok - równolegle do dziecka» (...), skupieniu uwagi na dziecku, poprzez obserwowanie go. (...) Ową umiejętność wychowawcy można oświetlić wprowadzając pojęcie autonomii uznawanej za proces pozwalający dziecku stawać się "przedsiębiorcą swojego własnego życia»" (Telka 2009: 54).

W żłobku - wydaje się, że zgodnie z rozwojem dziecka oraz jego potrzebą doświadczania - warto byłoby rozważyć rezygnację z pojęcia tzw. „zajęć” na rzecz pojęć: „aktywności rozwijających” oraz „zabaw rozwijających” jako nadrzędnych sposobów oddziaływań o charakterze kształcącym, jako nadrzędnych form aktywności dziecka. Zabawa jest dziecięcą przestrzenią do bezpiecznego wypróbowywania różnorodnych form myślenia (Gardner 1982: 255). Swobodna zabawa nie tylko pozwala dziecku na doskonalenie kompetencji kluczowych w procesie rozwoju na 
etapie wczesnego dzieciństwa, pozwala ona także opiekunom na obserwację bieżącego potencjału dziecka, jego zainteresowań, sposobu dziecięcego „zanurzenia się" w otaczającym dziecko świecie.

Poprzez aktywność rozwijającą można rozumieć samoistną aktywność dziecka oraz aktywności wynikające z możliwości oferowanych dziecku przez przestrzeń tworzoną przez opiekuna. Aktywność taka nie zawsze musi mieć charakter zabawy - np. w toku eksploracji otoczenia dziecko, przejawiając zainteresowanie określonym przedmiotem, zaczyna go rozpoznawać i manipuluje nim, by poznać jego właściwości. Taka aktywność pozbawiona jest ludycznych aspektów, ma jednak charakter edukacyjny - dziecko podczas manipulacji zdobywa wiedzę o przedmiocie i kształci umiejętności w zakresie motoryki. Podobnie - w toku np. ubierania dziecka - można zainicjować jego aktywność, sugerując mu wykonywanie określonych gestów, nazywając części odzieży, części ciała. Taka aktywność ma wymiar rozwijający, nie jest jednak zabawą. Przy pierwszej z nich może okazać się, że opiekun nie będzie potrzebny w toku kształcenia, stworzy warunki do eksploracji i będzie „obserwatorem” dziecięcej aktywności. W toku drugiej, zaproponowanej tu aktywności rozwijającej, opiekun będzie przewodnikiem, inicjatorem i współuczestnikiem procesu kształcenia.

Małe dziecko odkrywa świat, eksplorując otoczenie, manipulując przedmiotami i doświadczając tego otoczenia zmysłami (por. Eppler 1995: 391-405). Dziecko uczy się także poprzez naśladowanie. Opiekun ma towarzyszyć w rozwoju dziecka i tworzyć mu przestrzeń do dziecięcego samokształcenia - przestrzeń zgodną z dziecięcą potrzebą eksploracji i swobodnej zabawy. Opiekun - nauczyciel małego dziecka ma prowadzić je poprzez okoliczności sprzyjające poznaniu, poszerzaniu umiejętności, poprzez dialog i „bycie obok”.

\section{Założenia metodologiczne badań własnych i wyniki badań}

Celem podjętych badań było zweryfikowanie sposobów postrzegania wczesnej edukacji w żłobku przez personel żłobków publicznych na terenie Poznania ${ }^{4}$. Problem badawczy zawarto w pytaniu: w jaki sposób wczesną edukację w żłobku postrzegają opiekunowie żłobków publicznych?

\footnotetext{
${ }^{4}$ Warto nadmienić, że w Poznaniu funkcjonuje obecnie ponad 90 placówek niepublicznych, jednak w toku realizowanych przez autorkę badań okazało się, że większość placówek niepublicznych funkcjonuje na zasadzie silnej konkurencji, która powoduje dużą niechęć dyrektorów do współpracy z osobami nienależącymi do środowiska danego żłobka. Zamkniętą postawę większości dyrektorów potwierdza także Anna Ratajczak, która pod kierunkiem prof. Hanny Krauze-Sikorskiej przygotowywała oraz w 2017 r. na Wydziale Studiów Edukacyjnych UAM obroniła pracę doktorską na temat wspomagania rozwoju małego dziecka. Pozyskana przez Autorkę próba badawcza ograniczona jest do zaledwie kilku osób pochodzących ze środowiska instytucjonalnych form opieki nad dzieckiem do lat trzech. Warto także zauważyć, że personel opiekuńczy żłobków prywatnych legitymuje się na ogół bardzo krótkim stażem pracy (w przedziale od 0 do 5 lat). Opiekunkami dziecięcymi są na ogół osoby bardzo młode, legitymujące się wykształceniem wyższym na poziomie licencjatu, z niewielkim doświadczeniem zawodowym.
} 
Badanie za pomocą kwestionariusza ankiety przeprowadzono w lutym $2017 \mathrm{r}$. w Poznaniu. W sondażu diagnostycznym udział wzięły 74 respondentki - opiekunki dziecka do trzeciego roku życia zatrudnione w publicznych żłobkach na terenie Poznania (stanowiące niemal 100\% opiekunek zatrudnionych w poznańskich publicznych zespołach żłobkowych).

Spośród badanych respondentek najbardziej liczną grupę stanowią osoby ze stażem pracy większym niż 20 lat (23 osoby). Nieco mniej osób legitymuje się stażem pracy od 0-5 lat (20 osób). Powyżej 10 lat pracy, lecz mniej niż 15 lat w zawodzie opiekuna dziecka do trzeciego roku życia, pracuje 10 spośród badanych osób. Staż pracy pomiędzy 16 a 20 lat zadeklarowało 7 opiekunek, natomiast pomiędzy 6 a 10 lat zadeklarowało 14 osób.

Z opisanych wyżej danych wynika, że wśród poznańskich opiekunów żłobków publicznych większość stanowią osoby z doświadczeniem zawodowym wywiedzionym jeszcze z tradycji funkcjonowania żłobków przed 2011 r. To pozwala na przyjęcie założenia, że większość osób posiada znaczące doświadczenie zawodowe $\mathrm{w}$ pracy z małym dzieckiem w obszarze opieki i wychowania. Co wydaje się istotne - 20 spośród osób badanych to osoby ze stażem pracy nieobejmującym więcej niż 5 lat, co pozwala przypuszczać, że osoby te, „przekraczając” po raz pierwszy w dorosłym życiu próg żłobka, podejmowały aktywność zawodową w obszarze wczesnej edukacji wynikającą z tzw. „ustawy żłobkowej”. Opisane dane ukazuje rycina 1.

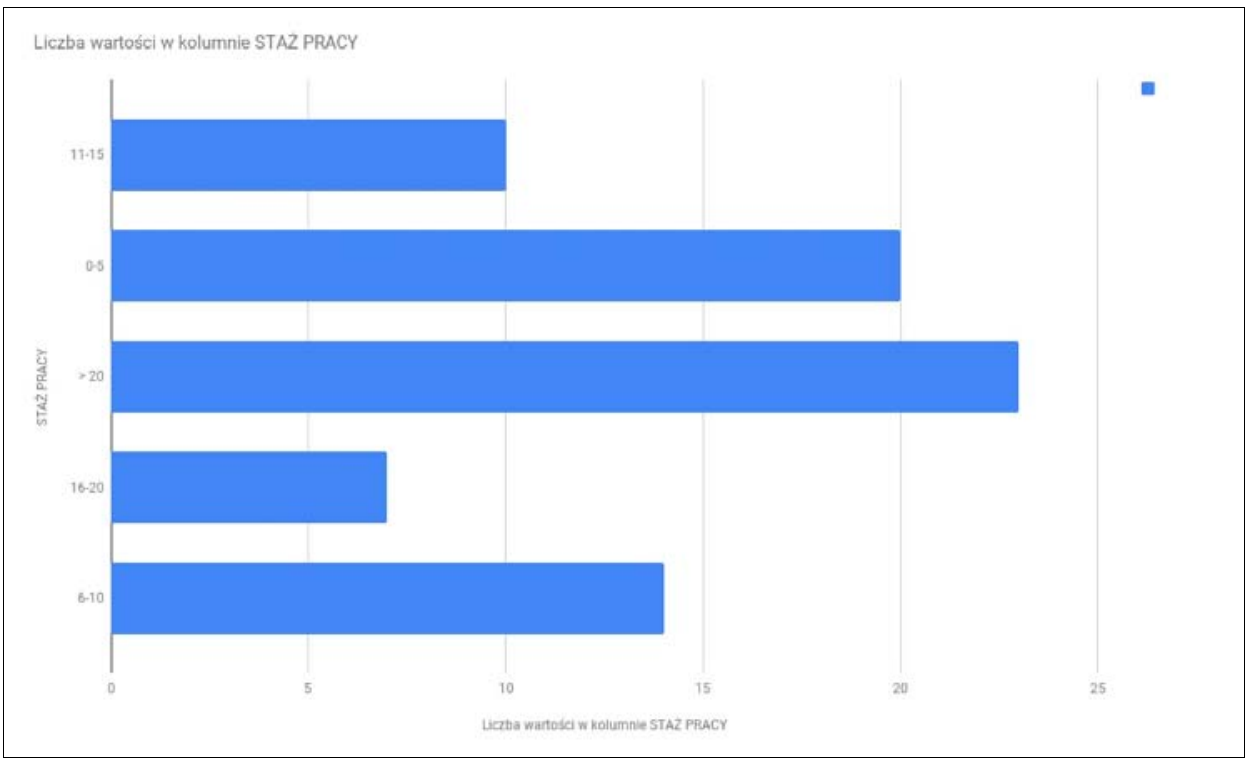

Ryc. 1. Staż pracy opiekunek do lat trzech pracujących w poznańskich żłobkach publicznych Źródło: opracowanie własne 
W poznańskich żłobkach publicznych pracuje 28 respondentek legitymujących się wykształceniem pedagogicznym. Kolejne 25 respondentek zdobyło kwalifikacje w drodze kursu zatwierdzonego przez Ministerstwo Rodziny, Pracy i Polityki Społecznej na opiekuna dziecka do lat trzech, 3 osoby określiły się mianem opiekunek dziecięcych, lecz nie podały typu zdobytych kwalifikacji. Spośród badanych jedna osoba ma kwalifikacje położnicze, jedna ukończyła Liceum Medyczne na Wydziale Opiekuna Dziecka, 14 badanych osób ma przygotowanie pielęgniarskie. Jedna respondentka deklaruje ukończenie pomaturalnego studium medycznego w zakresie opieki nad dzieckiem do lat trzech, dodatkowo - jedna osoba deklaruje, że kwalifikacje zdobyła w drodze ukończenia rocznej policealnej szkoły dla opiekunek dziecka do lat trzech. Jedna opiekunka nie podaje uzyskanego przygotowania do pracy z dzieckiem do lat trzech.

Powyższe dane wskazują, że personel poznańskich żłobków publicznych w znacznej mierze składa się $\mathrm{z}$ osób z przygotowaniem pedagogicznym. Można przyjąć, że osoby, które opisują swoje przygotowanie jako „opiekun dziecięcy”, są pracownikami z tzw. „doświadczeniem dwuletnim w pracy z dzieckiem”. Jest to zgodne z artykułem 16 ustawy, w której czytamy, że „opiekunem w żłobku lub klubie dziecięcym może być osoba posiadająca kwalifikacje: pielęgniarki, położnej, opiekunki dziecięcej, nauczyciela wychowania przedszkolnego, nauczyciela edukacji wczesnoszkolnej lub pedagoga opiekuńczo-wychowawczego” (Dz.U. 2011, nr 45, poz. 235). Artykuł ten określa, że „opiekunem w żłobku lub klubie dziecięcym może być także osoba, która posiada co najmniej wykształcenie średnie oraz co najmniej dwuletnie doświadczenie w pracy z dziećmi w wieku do lat 3” (Dz.U. 2011, nr 45, poz. 235). Założyć więc można, że osoby określające się mianem „opiekun dziecięcy” są osobami z tzw. „ustawowym” doświadczeniem, którego zakres jednak trudno jest dookreślić, bowiem ani ustawa z dnia 4 lutego 2011 r. o opiece nad dziećmi w wieku do lat 3, ani rozporządzenie MPiPS z dnia 25 marca 2011 r. (Dz.U., nr 69, poz. 368) nie podaje konkretnych kryteriów w zakresie „doświadczenia”, co pozwala w gruncie rzeczy na dość swobodną jego interpretację. Przygotowanie merytoryczne do pracy na stanowisku opiekuna dziecka do lat trzech w żłobku przedstawia rycina 2 .

Wszystkie badane osoby wyrażają przekonanie, że żłobek może stanowić dla dziecka realną szansę na wczesną edukację, można więc przyjąć, że każda z badanych opiekunek stara się tworzyć dziecku warunki prorozwojowe oraz nie ogranicza się wyłącznie do sprawowania opieki, lecz podczas pracy z dzieckiem poszukuje sytuacji potencjalnie edukacyjnych. Przeświadczenie o tym, że żłobek może być miejscem wczesnej edukacji realizowanej w przyjaznym dziecku środowisku wyrażone przez wszystkie respondentki jest bardzo satysfakcjonującym wynikiem, pozwala bowiem założyć, że edukacyjną funkcję żłobka dostrzegają nie tylko osoby z przygotowaniem pedagogicznym, lecz także osoby wywodzące się ze szkół medycznych, pielęgniarskich, a także opiekunowie zdobywający kwalifikacje podczas 
„ministerialnego” kursu czy osoby z „doświadczeniem”. Budującym wydaje się także, że edukacyjną funkcję żłobka dostrzegają osoby zatrudnione na stanowisku opiekuna małego dziecka jeszcze przed 2011 r. (a jak już wskazano, jest to ponad połowa respondentów), w którym do tzw. „ustawy żłobkowej” wprowadzono funkcję edukacyjną żłobka. Wynik ten oznacza, że istnieje możliwość, iż prorozwojową funkcję placówek opieki nad małym dzieckiem dostrzegano jeszcze w czasach, gdy te należały do resortu zdrowia.

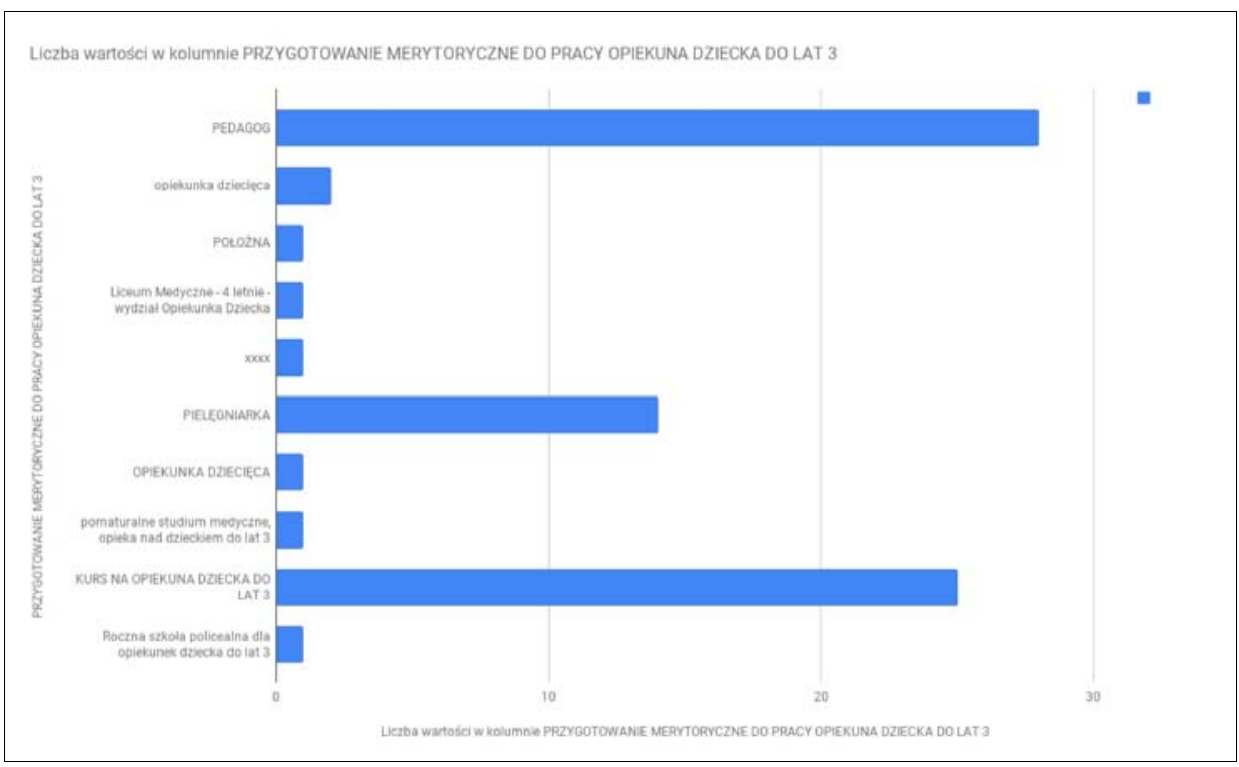

Ryc. 2. Przygotowanie merytoryczne do pracy opiekuna dziecka do lat trzech

Źródło: opracowanie własne

Respondentki zapytane o to, w jaki sposób współczesny żłobek wspiera rozwój dzieci, udzielały dość zróżnicowanych odpowiedzi. Opinie te można jednak podzielić na różne kategorie.

Pierwszą z nich jest kategoria zawierająca wypowiedzi pracowników żłobków, w których dostrzec można aktywność dziecka i tworzenie mu przestrzeni do aktywności i zabawy. W ramach wypowiedzi mieszczących się w tej kategorii badane osoby zwracają uwagę na:

- pożytki płynące z przebywania dziecka w grupie, na przykład: rozwój mowy, poznawanie zasad życia społecznego;

- możliwość zabawy różnorodnymi zabawkami - „organizowanie zabaw w kącikach tematycznych”, „zabawy i zabawki dostosowane do wieku i sytuacji”;

- możliwość podejmowania przez dziecko różnych aktywności - na przykład „zajęcia manipulacyjne, konstrukcyjne, edukacyjne”; 
- obecność opiekunki, która wspiera także indywidualnie każde dziecko „wplatanie elementów edukacyjnych do czynności opiekuńczych oraz zaspokojenie jego potrzeb psychicznych";

- możliwość uczenia się przez dziecko określonych umiejętności - samodzielnego jedzenia, higieny - „wspieranie rozwoju na wszystkich etapach poprzez naśladownictwo, zabawę, każda czynność opiekuna ma być kolejnym kroczkiem do przodu, pokonywaniem kolejnego szczebla drabiny rozwojowej";

- zapewnienie warunków poczucia bezpieczeństwa dziecka - „tworząc miłą i przyjazną atmosferę, sprawiając radość dziecku z samego pobytu", zapewniając „powtarzalność czynności, regularność trybu dnia”.

Wypowiedzi respondentek, które wydają się najbardziej trafne w odniesieniu do pojęć związanych z wczesną edukacją dziecka dotyczą zabawy, poznawania, nauki samodzielności, wspierania rozwoju na wszystkich etapach poprzez naśladownictwo, gdy „każda czynność opiekuna ma być kolejnym kroczkiem do przodu, pokonywaniem kolejnego szczebla drabiny rozwojowej” przez dziecko. Przyjmując, że

kluczem powodzenia we wczesnej edukacji jest dopasowanie metod wspierania rozwoju dziecka do fazy rozwojowej, w której aktualnie się znajduje, np. roczne dziecko nie jest zwykle w stanie wypełnić nawet krótkiego polecenia instrukcji innej osoby - lepsze dla niego będzie zademonstrowanie danej czynności i potem wykonanie jej razem z dzieckiem, ale trzylatek może już przez dłuższą chwilę spokojnie posiedzieć i „poczytać” książeczkę razem z mamą (Kram, Mielcarek 2014: 8),

trafnym sformułowaniem jest także to, które zaznacza, że wspieranie rozwoju następuje „poprzez zabawy edukacyjne dostosowane do wieku dziecka” (tamże).

Ponieważ najbardziej charakterystyczną formą aktywności dziecka do lat trzech w kulturze europejskiej jest zabawa, dziecko uczy się poprzez zabawę i jest to dla niego sytuacja naturalna. W związku z powyższym warto zwrócić uwagę na fakt, że w deklaracjach wielu opiekunek pojawia się pojęcie zabawy. Jest to szczególnie istotne z tego względu, że podczas podejmowania aktywności zabawowej dziecko przekracza granice „własnych umiejętności i zdolności” (tamże: 8).

Druga kategoria wypowiedzi pracowników żłobków koncentruje się wokół pojęcia kwalifikacji lub rodzajów aktywności personelu opiekuńczego. W ramach czynionych deklaracji opiekunki zwracają uwagę na:

- kwalifikacje uprawniające do podjęcia pracy na stanowisku opiekuna dziecka do lat trzech - „wykwalifikowany personel, który dba o każdą strefę rozwoju dziecka";

- potrzebę ustawicznego kształcenia warsztatu pracy opiekuna małego dziecka - „przez edukację personelu”, „szkolenia dla opiekunek”, „edukacja, podnoszenie kwalifikacji personelu"; 
- aktywność opiekuna małego dziecka - „indywidualna praca z dzieckiem, praca w grupie”, „rytmika, odpowiednie zabawy dydaktyczne, zakup odpowiednich zabawek dostosowanych do wieku".

Z powyższych deklaracji wynika, że opiekunki przywiązują wagę do kwalifikacji, jednakże trudno jest wnioskować, na ile kwalifikacje te przekładać się będą na efektywność w zakresie wspierania rozwoju, bowiem respondentki nie uzasadniają wyrażonych opinii w kontekście wspierania rozwoju dziecka. Nie sprecyzowano także, co respondentki rozumieją pod pojęciem wykwalifikowanej kadry. Wysokie kwalifikacje oraz ustawiczne kształcenie wpisane jest niestety raczej w zawód nauczyciela, opiekun w żłobku pozbawiony jest możliwości awansu zawodowego, co w dużej mierze determinować może sposób postrzegania przez respondentki pojęć, takich jak samokształcenie, edukacja czy też kwalifikacje. Warto też zasygnalizować, że znowelizowana w 2017 r. ustawa o opiece nad dziećmi do lat trzech rozszerza znacznie zakres osób uprawnionych do podjęcia pracy na stanowisku opiekuna małego dziecka, co z całą pewnością nie będzie sprzyjać wysokim standardom kwalifikacji zawodowych pracowników żłobka. Ustawa oraz rozporządzenie o szkoleniach uprawniających do podjęcia pracy w żłobku (Rozporządzenie Ministra Pracy i Polityki Społecznej z dnia 25 marca 2011 r. w sprawie zakresu programów szkoleń dla opiekuna w żłobku lub klubie dziecięcym, wolontariusza oraz dziennego opiekuna, Dz.U., nr 69-4333, poz. 368) konsekwentnie pomijają też wytyczne krajowego standardu kwalifikacji zawodowych, według którego osoba pracująca z dzieckiem w żłobku nie jest tylko i wyłącznie opiekunem, a wychowawcą (por. Krajowy Standard Kompetencji Zawodowych, Wychowawca małego dziecka (234202), Ministerstwo Pracy i Polityki Społecznej, Warszawa 2013).

W odniesieniu do opinii respondentek warto zauważyć, że opiekunki, które wydają się dostrzegać korelację pomiędzy własnymi kwalifikacjami a jakością procesu wspierania rozwoju dziecka wpisują się w model założeń „towarzyszenia w rozwoju", wpisują się także w koncepcję pedagogiki w żłobkach w Reggio Emilia (por. Malaguzzi 1993: 10).

Trzecia kategoria to wypowiedzi wymijające lub bardzo ogólne, np.: „współczesny żłobek nie tylko ma funkcję opiekuńczą, ale też rozwija i wychowuje", „codzienna opieka i pielęgnacja dająca mu (dziecku) poczucie bezpieczeństwa”, „opieka w codziennym pobycie dziecka, zajęcia stymulujące, nauka radzenia sobie w grupie". Wypowiedzi zawarte w tej kategorii są nieprecyzyjne i mogą świadczyć z jednej strony o małym doświadczeniu, z drugiej jednak strony przywodzą na myśl stereotypowe lub rutynowe podejście do pracy z małym dzieckiem znane z okresu PRL (por. Polakowski, Szelewa 2015: 14-15). Deklaracje te nie pozwalają na ustalenie, w jaki sposób, zdaniem tychże respondentek, współczesny żłobek mógłby wspierać rozwój dziecka.

Wśród deklaracji osób biorących udział w badaniu największe kontrowersje budzą wypowiedzi, które: 
- koncentrują się wyłącznie na naśladownictwie jako metodzie kształcenia - „żłobek uczy współdziałania w grupie, dostosowania się do panujących zasad, jak wiadomo dzieci uczą się przez naśladownictwo, dlatego m.in. w ten sposób wspiera się ich rozwój"

- pomijają wszelką aktywność ludzką - „dobre wyposażenie w zabawki i wykwalifikowany personel";

- koncentrują się na dostosowaniu dziecka do organizacji pracy w żłobku - „nauka samodzielnego spożywania posiłków, dostosowywanie się do norm”, „nauka samodzielności, odzwyczajanie od pieluchy, uczenie zasad grzecznościowych";

- akcentują pojęcie „nauka”, które można uznać za pojęcie zbyt wąskie, by określić sposoby stymulowania rozwoju dziecka - „nauka samodzielności, nauka zachowania w różnych sytuacjach";

- koncentrują się wyłącznie na „nauce” samodzielności - „dzieci uczą się samoobsługi";

- zawężają obszar oddziaływań opiekuna wyłącznie do czynności opiekuńczych - „ze względu na częste alergie - dostosowywanie diet, szczepienia ochronne, możliwość opieki już od 6.00";

- postrzegają edukację małego dziecka dyrektywnie i formalnie - „zajęcia edukacyjne”, „zapewnienie dziecku zajęć edukacyjnych”.

Podsumowując analizę odpowiedzi respondentek dotyczących możliwości żłobka we wspieraniu rozwoju dziecka, należy zaznaczyć, że 11 osób nie udzieliło odpowiedzi na pytanie. W wynikach badań dostrzec można znaczne różnice w postrzeganiu sposobów wspierania rozwoju dziecka w żłobku, co jest o tyle niepokojące, że zadaniem opiekuna jest codzienne wspieranie i stymulowanie dziecka, które nie będzie dokonywało się na przykład poprzez uczenie podopiecznych zwrotów grzecznościowych, lecz w procesie konkretnych oddziaływań i we wzajemnej diadzie „opiekun - dziecko”. Deklaracje wyżej przedstawione ukazują także szereg trudności z definiowaniem pojęcia wspierania rozwoju, oscylują wokół obszaru opiekuńczego i niejednokrotnie powielają stereotyp dotyczący przekonania, że tam gdzie realizuje się zajęcia, tam mamy do czynienia z edukacją.

Respondentki w zróżnicowany sposób postrzegają oczekiwania rodziców wobec opiekunów dziecka w żłobku. Pięć osób spośród badanych odpowiada „nie wiem", co wskazuje raczej na niski poziom zaangażowania opiekuna w budowanie relacji z rodzicami. Kilka osób nie udzieliło odpowiedzi na pytanie o oczekiwania rodziców, poza tym można wyróżnić kategorię odpowiedzi o krytycznym wobec rodziców zabarwieniu oraz kategorię odpowiedzi nastawionych na budowanie relacji z rodzicami dzieci powierzanych placówkom. Zaznaczyć należy w tym miejscu, że zadaniem wychowawcy - nauczyciela małego dziecka jest budowanie

\footnotetext{
5 Wypowiedź ta koncentruje się wyłącznie na naśladownictwie jako metodzie kształcenia, ponadto dostrzec w niej można zamiar tzw. „urabiania dziecka”.
} 
więzi z jego środowiskiem rodzinnym, które jest dla dziecka środowiskiem naturalnym. Sposób funkcjonowania dziecka w rodzinie nadaje istotny kontekst indywidualizacji sposobu stymulowania rozwoju dziecka w środowisku instytucjonalnym.

W kategorii wypowiedzi pracowników żłobków o krytycznym zabarwieniu zawierają się m.in. takie, które:

- wskazują na niechęć opiekunek wobec rodziców - oto niektóre wypowiedzi:

rodzice są bardzo roszczeniowi. Ciężko się z nimi współpracuje. Dużo wymagają od nas a sami nie potrafią współpracować. Takie zachowanie powoduje, że dziecko ma chaos w głowie, rodzic wymaga wręcz od opiekunów aby nauczyć i wychować latorośl. Sami wkładają w ten proces minimalny wysiłek (choć nie każdy rodzic taki jest);

- sformułowane są w ironicznym tonie - „ogromne, dziecko winno wrócić do domu zmęczone i śpiące, aby szybko poszło spać”, „dziecko ma być nakarmione, czyste i wybawione";

- mają charakter skargi lub żalu na okoliczność tzw. „przerzucania odpowiedzialności” - bowiem rodzice „wymagają więcej od opiekunów niż od siebie samych (nauka samodzielnego jedzenia)”, „mamy dzieci wszystkiego nauczyć, tzw. spychologia”, „rodzice najczęściej są roszczeniowi, bywa że wymagają rzeczy nieosiągalnych i niemożliwych, natomiast od siebie nie wymagają niczego. Trudno jest im przynieść dodatkową parę majteczek dla dziecka”, „są roszczeniowi, oczekują "gotowego produktu», nie współpracują z personelem”, „wymagają dużo od opiekunów, a sami często odmawiają współpracy";

- zwracają uwagę na wymagania rodziców związane $\mathrm{z}$ indywidualizacją oddziaływań wobec dziecka - „najlepsza byłaby indywidualna opieka”, „ich dziecko ma być w centrum zainteresowania, ma być najważniejsze";

- zaznaczają, że rodzic oczekuje, iż opiekun dziecka w żłobku powinien go zastąpić - „opiekunki mają zastępować rodziców”, „często powstaje wrażenie, że mamy rodzica «zastąpić»".

Ostatnie wypowiedzi mogą być pochodną funkcjonującego w społeczeństwie stereotypu żłobka, w którym, jak pisze m.in. Danuta Łosiewicz, „panują prawa dżungli", więc jeśli już trzeba wybrać placówkę pozarodzinną dla dziecka, to taką, zdaniem autorki tekstu, która oddaje atmosferę domu, nadto taką, w której wychowawcy będą „imitować” mamę (Łosiewicz 2013: 34). Warto jednak zaznaczyć, że opiekun nie ma obowiązku imitować rodzica ze względu na to, że naturalnym środowiskiem dziecka powinna być rodzina i dziecko należy w takim przekonaniu kształtować. Powinnością opiekuna jest niewątpliwie stwarzanie atmosfery bezpieczeństwa, akceptacji i miłości, jednakże dziecko musi mieć świadomość, że opiekunka nie jest mamą, a opiekunką, tym samym - ma ona inny zakres obowiązków.

Do kategorii wypowiedzi osób nastawionych pozytywnie na budowanie relacji z rodzicami należą wypowiedzi, które w sposób przejrzysty i pozbawiony swoiste- 
go „żalu” określają oczekiwania rodziców wobec opiekunów - wskazują przede wszystkim takie cechy, jak: „profesjonalizm, odpowiednie podejście do dzieci, miła atmosfera, łatwy kontakt z opiekunem, bezpieczne otoczenie dziecka, odpowiedni plan zajęć dla odpowiedniego wsparcia rozwoju dziecka, dokładna obserwacja postępów i ich dokumentowanie".

Także w kategorii deklaracji opiekunek gotowych na budowanie relacji z rodzicami znajdują się wypowiedzi, które akcentują z jednej strony pozytywny stosunek rodziców do opiekunów, z drugiej wskazują na rodziców „zamkniętych” na sugestie respondentek - „są dwie grupy rodziców - jedna grupa oczekuje, że będziemy rodziców wyręczać we wszystkim, druga grupa aktywnie współuczestniczy w procesie edukacji i opieki - pyta, docieka, słucha wskazówek i podpowiedzi opiekunów".

Podsumowując analizę wypowiedzi opiekunek, można stwierdzić, że oczekiwania rodziców, którzy powierzają dzieci opiece żłobkowej, są dwojakiego typu:

- pierwsza kategoria rodziców nastawiona jest na zdobywanie informacji o dziecku, na prowadzenie dialogu z opiekunem, na troskę o to, by dziecko było traktowane podmiotowo, przebywając poza własnym środowiskiem rodzinnym, by rozwój dziecka był stymulowany, o czym świadczą wypowiedzi na temat próśb rodziców o obserwację dziecka czy monitorowanie jego postępów;

- druga kategoria rodziców opisana jako dość „roszczeniowa” (co wnioskować można nie tylko w wyniku analizy wypowiedzi opiekunek, lecz także w wyniku stosowania przez nie w kilku wypowiedziach ironii). Zdaniem respondentek są to rodzice, którzy czują się zwolnieni z wykonywania obowiązków rodzicielskich ze względu na fakt powierzenia dziecka instytucjonalnej opiece.

Opiekunowie w większości są nastawieni na współpracę i budowanie pozytywnych relacji z rodzicami, co z całą pewnością można sklasyfikować jako korzystne zjawisko, które w zdecydowany sposób decydować będzie nie tylko o tworzeniu przyjaznej atmosfery prorozwojowej wokół dziecka, ale także ma szansę odmienić stereotyp żłobka jako instytucji „zamkniętej”. Należy jednak zauważyć, że wśród opiekunów zatrudniane są także osoby krytycznie nastawione wobec rodziców lub zupełnie obojętne wobec konieczności współdziałania ze środowiskiem rodzinnym na rzecz rozwoju dziecka. Tego typu sytuacja wymyka się standardom wczesnej edukacji i opieki nad dzieckiem, bowiem współdziałanie i budowanie wzajemnych relacji środowisk wychowawczych dziecka jest podstawowym warunkiem powodzenia w procesie harmonijnego jego rozwoju.

Pytanie o to, w jaki sposób można określić wczesną edukację w żłobku, dostarcza opiekunkom znaczących problemów, co wynika z niejednolitego definiowania tego pojęcia nawet na gruncie dostępnej literatury przedmiotu. Wśród definicji podanych przez respondentki pojawiają się jednak takie, które pozwalają na wysnucie przypuszczenia, że wczesna edukacja dziecka w żłobku rozumiana jest 
przez nie w sposób adekwatny do wytycznych psychologii rozwojowej i niektórych ujęć pedagogicznych. Wśród wypowiedzi, które w jakimś stopniu oddają założenia wczesnej edukacji dziecka, znajdują się:

- ukierunkowane w stronę stymulowania i obserwacji rozwoju - „obserwacja rozwoju dziecka, stymulacja rozwoju";

- akcentujące zabawę jako środek wspierania rozwoju dziecka - „kształtowanie i rozwój dziecka przez opiekę i zabawę";

- dostrzegające potrzebę interakcji z dzieckiem - „rozmowa z dzieckiem, objaśnianie poszczególnych przedmiotów (do czego służą)";

- dostrzegające wartość nauczania okolicznościowego i tworzenia potencjalnych sytuacji edukacyjnych - „każda sytuacja, kiedy spotykamy człowieka”, „edukacja to gesty, mimika, jak również pielęgnacja, w trakcie której można przekazać wiele informacji”, „stymulacja dziecka przez otoczenie”;

- zwracające uwagę na konieczność dostosowania oddziaływań do potrzeb dziecka - „dostosowywanie metod wspierania rozwoju do fazy rozwojowej i wieku dziecka".

Inna niż wyżej wymieniona kategoria wypowiedzi świadczy o życzliwym podejściu opiekunów do dziecka, przeważa w nim jednak czynnik opiekuńczy - „uśmiech do dziecka, dotyk i rozmowa z dzieckiem”, „opieka, pielęgnacja, mówienie, co wolno, a co nie wolno".

Wśród wypowiedzi respondentek znalazły się również takie, które przeczą założeniom wczesnej edukacji. Charakter tych wypowiedzi przywodzi na myśl stereotypowe postrzeganie żłobka jako instytucji, która przede wszystkim rozwija samodzielność i samoobsługę, „ucząc go podstawowych rzeczy, sygnalizowania potrzeb, używania łyżeczki, picia z kubeczka”, „rozwijanie podstawowych funkcji życiowych, jak np. rozbieranie, ubieranie, rozwijanie wyobraźni"6.

Kolejna kategoria deklaracji akcentuje przyszłość dziecka, opisując wczesną edukację w kategoriach przystosowania do dalszej drogi edukacyjnej (brakuje tu jednak zorientowania na wspieranie rozwoju bieżącego). Przykładem są następujące wypowiedzi: „przystosowanie do edukacji w przedszkolu”, „przystosowanie do dalszego życia”, „jako pomoc w dalszym etapie współżycia w społeczeństwie. Pożłobkowe dzieci w przedszkolu są bardziej samodzielne i zaradne".

Aż 13 badanych osób uważa, że wiodącą funkcją żłobka jest funkcja opiekuńcza, jednocześnie 29 osób zaznacza, że funkcje: opiekuńcza, wychowawcza i edukacyjna są funkcjami równoważnymi lub równorzędnymi w procesie oddziaływań wobec dzieci do lat trzech (choć opinię tę wyrażają nie zawsze w jednoznaczny sposób). Dziewięć osób nie ma w tej kwestii zdania, lecz są i takie osoby, które funkcje te różnicują w zależności od wieku dziecka. Pojedyncze opinie dotyczą tego, że funkcja opiekuńcza jest wiodącą do ukończenia przez dziecko pierwszego roku

\footnotetext{
${ }^{6}$ Warto także zaznaczyć, że wymienione w cytacie czynności nie są podstawowymi funkcjami życiowymi.
} 
życia. Wśród deklaracji respondentów znajduje się także opinia, że funkcja opiekuńcza przejawia się w liczebności grupy dzieci wobec opiekuna. Jedna z respondentek wyraża przekonanie, że najważniejszą jest funkcja edukacyjna. Wśród odpowiedzi są jednak takie, które trudno jest jednoznacznie zinterpretować.

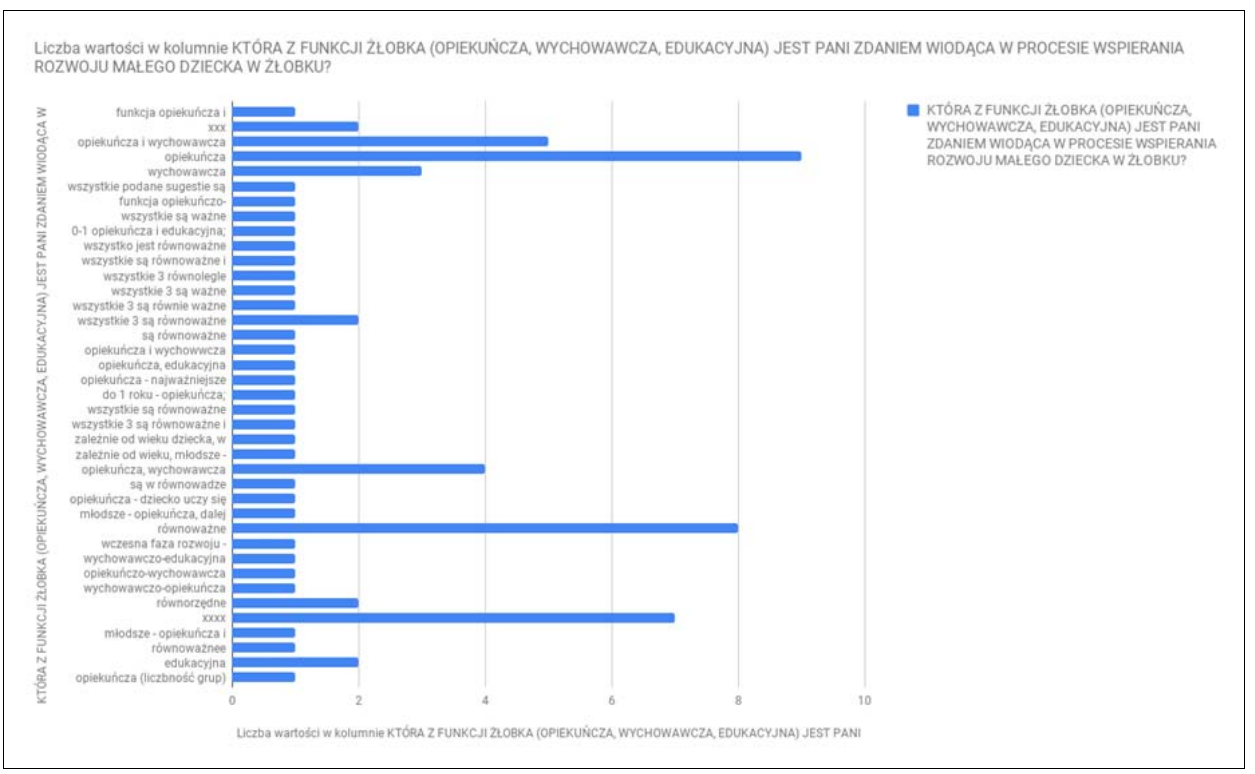

Ryc. 3. Opinie opiekunów dziecka do lat 3 na temat wagi poszczególnych funkcji żłobka: opiekuńczej, wychowawczej i edukacyjnej

Źródło: opracowanie własne

Respondentki zapytano także o to, jakie umiejętności i jaką wiedzę chciałaby dodatkowo nabyć lub poszerzać (doskonalić), jakie zagadnienia (np. podczas szkoleń) byłyby dla nich pomoce w toku codziennej pracy. Uzyskane wyniki badań wskazują na to, że 28 osób nie widzi potrzeby podnoszenia kwalifikacji, pozostałe osoby natomiast zgłaszają różnorodne potrzeby, spośród których wyszczególnić można:

- potrzebę doskonalenia w zakresie organizacji zabaw - „rozmaite zabawy”;

- potrzebę doskonalenia w zakresie organizowania wczesnodziecięcej edukacji - „edukacja małego dziecka”;

- potrzebę doskonalenia kompetencji w zakresie komunikacji interpersonalnej - „Jak rozmawiać z rodzicami, aby nas słuchali, aby chcieli współpracować dla dobra swoich dzieci";

- potrzebę doskonalenia pracy z dziećmi w potencjalnie trudnych sytuacjach - „jak radzić sobie z 2-3-latkiem w okresie buntu. Jak z nim rozmawiać, jak dotrzeć do dziecka, które jest na etapie - nie"; 
- potrzebę doskonalenia w zakresie obserwacji i diagnozy rozwoju dziecka - „anatomia dziecka i jej nieprawidłowości dla 0-3 i jej wyłapywanie”, „współpraca z rodzicami, korygowanie nieprawidłowości i zaburzeń dziecka”;

- potrzebę doskonalenia praktycznego warsztatu pracy - „zagadnienia praktyczne i ich przykłady”, „prowadzenie zajęć umuzykalniających”, „zajęcia z muzyką", „animator zabawy”.

Na pytanie: Jakie problemy rozwojowe dzieci dostrzega Pani podczas codziennej pracy z żłobku? Z jakimi specjalistami, Pani zdaniem, warto współpracować na rzecz rozwoju dzieci? udzielono także zróżnicowanych odpowiedzi.

Pierwszą kategorię tworzą wypowiedzi pracowników żłobków wskazujące na chęć współpracy z określonymi specjalistami. W ramach deklaracji dwie osoby rekomendowały potrzebę współpracy z ortopedą i logopedą, także psychologiem, jedna z osób rekomendowała współpracę z logopedą, psychologiem i rehabilitantem, jedna osoba chciałaby współpracować z psychologiem, pediatrą, psychiatrą, alergologiem. Deklaracja o chęci współpracy z psychologiem i logopedą pojawia się jeszcze $w$ dwunastu deklaracjach poszerzonych także $w$ jednostkowych przypadkach o postulat współpracy z pediatrą, rehabilitantem, terapeutą, fizjoterapeutą, specjalistą od rytmiki, osiem osób wskazuje wyłącznie psychologa, siedem wyłącznie logopedę, jedna wypowiedź obok logopedy i ortopedy wskazuje też na chęć współpracy z muzykiem, w jednej z wypowiedzi pojawia się postulat o nawiązanie współpracy $\mathrm{z}$ dietetykiem. W jednej wypowiedzi odnajdujemy także potrzebę współpracy z pedagogiem specjalnym, animatorami, lekarzami specjalistami.

Druga kategoria wypowiedzi wskazuje na obserwowane problemy rozwojowe dzieci i - w wyniku tych obserwacji - określone postulaty. Najczęściej pojawia się postulat o współpracę z psychologiem w związku z częstymi sytuacjami trudnymi, wynikającymi z odmiennych niż oczekiwane zachowań dziecka, na przykład agresja, nadpobudliwość, wycofanie. Pojawia się także postulat o współpracę z logopedą, neurologiem, pediatrą, rehabilitantem, fizjoterapeutą w związku z przypuszczeniem nieprawidłowości rozwoju oraz zaburzeń rozwojowych dzieci - podejrzenia autyzmu, dysfunkcje ruchowe, wadliwa wymowa, upośledzenia, przykurcze, napięcia mięśniowe, nieprawidłowy chód u dziecka. Jedna z osób zwraca uwagę na problem dzieci z rodzin niepełnych i w związku z tym problemem rekomenduje współpracę z psychologiem.

Ostatnia kategoria wypowiedzi zawiera tzw. wypowiedzi różnorodne. $\mathrm{W}$ tym na przykład:

- zwracające uwagę na problemy adaptacyjne dzieci w trakcie roku - „po weekendzie, praca od nowa nad samodzielnością w czynnościach (picie z kubeczka, łyżeczka)”;

- naznaczające dzieci - „upartość, złośliwość, brak współpracy z rodzicami - koniecznie psycholog";

- zwracające uwagę na problem warunków pracy z dziećmi - „za dużo dzieci w grupie i za mało opiekunek"; 
- naznaczające rodziców - „brak współpracy z rodzicami, spóźnianie się do placówki, psycholog żeby szkolić rodziców i personel”, „Część rodziców jest zdziwionych, że my tu prowadzimy «jakieś zajęcia» - pytają «po co?» myślą że dziecko wystarczy nakarmić i przewinąć".

W wyniku powyżej zasygnalizowanych danych można przyjąć, że najbardziej pożądanymi specjalistami, o których postulują opiekunki dziecka do trzeciego roku życia, są psycholog, logopeda, rzadziej rehabilitant, psychiatra i inni. Problematycznym wydają się te określenia, które odnoszą się do obserwacji „agresji”, „nadpobudliwości”, „zaburzeń emocjonalnych” czy „nieprawidłowej mowy” u dzieci do trzeciego roku życia. Trudno jest stwierdzić, czy opisywane przez opiekunów zachowania dzieci są wynikiem zaburzenia czy dysharmonii, czy wiążą się bezpośrednio z labilnością emocjonalną charakterystyczną dla wczesnego dzieciństwa, czy agresja to nie przejawy negatywizmu dziecięcego i kształtowania się poczucia własnego ja, czy mowa faktycznie jest zaburzona, czy aspekt ten dotyczy kwestii artykulacji, która, ze względów rozwojowych na tym etapie życia dziecka, nie będzie taka jak artykulacja osoby dorosłej. Trudno też zdefiniować pojęcie nadpobudliwości dziecka do trzeciego roku życia, gdyż często dziecko takie - ze względu na prawidłowości rozwojowe - jest dzieckiem „żywym”, zainteresowanym wieloma kwestiami na raz, skoncentrowanym na danej czynności przez krótki czas jej trwania. Te pytania należy więc pozostawić jako otwarte ze względu na fakt, że w wypowiedziach opisano je w bardzo „oględny” sposób. Sformułowania dotyczące złośliwości dzieci oraz ich upartości świadczą z całą pewnością o niskich kompetencjach osoby je wyrażającej. Z deklaracji wynika także, że część osób biorących udział w badaniu dostrzega problemy związane z brakiem współpracy z rodzicami.

\section{Wnioski}

Podsumowując wyniki badań, można stwierdzić jednoznacznie, że obszar wczesnej edukacji wśród pracowników żłobków publicznych na terenie Poznania nie jest jednoznacznie rozumiany i definiowany. Brak jednolitego postrzegania wczesnodziecięcej edukacji przez osoby pracujące z dziećmi nie jest jednak niczym zaskakującym, bowiem ani ustawa, ani kolejne rozporządzenia Ministerstwa Rodziny, Pracy i Polityki Społecznej nie dookreślają ram wczesnodziecięcej edukacji. Ponadto na polskim rynku wydawniczym brakuje nadal opracowań dotyczących efektywnych metod organizowania pracy $\mathrm{z}$ dzieckiem. Nieliczne prace na ten temat nie są należycie upowszechniane. Brakuje także przewodników metodycznych dla opiekunów, brakuje instytucji doradczych, narzędzi motywujących personel żłobków do podnoszenia kwalifikacji.

Tym bardziej cennym wynikiem z badań jest ten, który pozwala przypuszczać, że opiekunki mają wiele potrzeb w zakresie poszerzania wiedzy i umiejętności, 
większość z nich jest otwarta na propozycje szkoleń, warsztatów. Opiekunki chcą doskonalić się raczej w zakresie organizowania dzieciom określonych aktywności, zabaw, zajęć, nie wyrażają jednak potrzeb uczestnictwa w formach kształcenia zawodowego związanych z obserwacją, diagnozą dziecka, indywidualizacją metod pracy. Wydaje się więc, że personel opiekuńczy w większości przypadków nie jest jednak ukierunkowany na niedyrektywne towarzyszenie dziecku w rozwoju, nie postrzega metod pracy z dzieckiem przez pryzmat jego własnej aktywności, lecz aktywności organizowanej przez dorosłego. Z deklaracji badanych osób wynika raczej postulat o szkolenia, które miałyby się odbywać po to, aby opiekun mógł „lepiej radzić sobie w pracy z dziećmi”, nie natomiast po to, by „dzieci lepiej się rozwijały".

Mając na uwadze, że większość biorących udział w badaniu opiekunek to osoby chętne do podnoszenia kwalifikacji, warto byłoby rozważyć stworzenie pewnych ram wczesnodziecięcej edukacji, ram awansu zawodowego osób pracujących z małym dzieckiem, a także instytucji oferujących doradztwo pedagogiczne pracownikom żłobków. Zawód opiekuna małego dziecka nie jest zawodem cieszącym się w Polsce powszechnym uznaniem, nie wiąże się z możliwością awansu (jak choćby w przypadku zawodu nauczyciela), jest jednak zawodem niezwykle odpowiedzialnym, trudnym, wymagającym od dorosłego ustawicznego wglądu w siebie, ustawicznej obserwacji wychowanka, z którym komunikacja odbywa się najczęściej na poziomach niewerbalnych.

Warto byłoby także uświadamiać społeczeństwu polskiemu misję żłobków jako miejsc prorozwojowych, przyjaznych dzieciom, tworzonych z myślą o wczesnodziecięcej edukacji postrzeganej przez pryzmat wspierania harmonijnego i indywidualnego rozwoju dziecka.

Pomimo że wczesnodziecięca edukacja jest tematem budzącym wiele kontrowersji i wyraźnie potrzebuje zdefiniowania, „budującym” wnioskiem sformułowanym w oparciu o wyniki omówionych w tekście badań jest ten, że personel żłobków dostrzega edukacyjny aspekt własnej pracy, co pozwala na pozytywne prognozy $\mathrm{w}$ procesie budowania nowego wizerunku żłobka jako miejsca prorozwojowego.

\section{Bibliografia}

Arnold C. (2009) Sharing ideas whit parents about key child development concepts w: Involving parents in their Children's Learning, M. Whalley (red.), London, Sage.

Eppler M. A. (1995) Development of manipulatory skills and the deployment of attention, "Infant Behavior and Development", no 18.

Gardner H. (1982) Developmental Psychology, Boston, Little, Brown \& Co.

Gerber M. (1979) A Manual for Parents and Professionals, Resources for Infant Educators, Los Angeles. 
Hammond R. A. (2009) Respecting babies: A new look at Magda Gerber's RIE approach, DC: Zero to Three, Washington.

Kram A., Mielcarek M. (2014) Wczesna edukacja dziecka. Wiek 0-2/3 w: Niezbędnik dobrego nauczyciela. Edukacja w okresie dzieciństwa i dorastania, tom I, A. Brzezińska (red.), Warszawa.

Kupisiewicz Cz. (2010), Szkice z dziejów dydaktyki, Kraków, Oficyna Wydawnicza „Impuls”.

Łosiewicz D. (2013) Stres żłobkowy, „wSieci” 2013, nr 3-9.

Malaguzzi L. (1993) For an education based on relationship, „Young Children”, November.

Marynowicz-Hetka E. (2009) Pedagogika społeczna. Podręcznik akademicki, t. I, Warszawa, Wydawnictwo Naukowe PWN.

Polakowski M., Szelewa E. (2015) Warszawskie debaty o polityce społecznej. Polityka społeczna PRL, Warszawa, Friedrich-Ebert-Stiftung.

Segiet K. (2014) Dzieciństwo na miarę oczekiwań rodziców - problemy i wyzwania w: Oblicza trudnego dzieciństwa. Konteksty rodzinno-edukacyjne, M. Cywińska (red.), Poznań, Wydawnictwo Naukowe UAM.

Telka L. (2009) Przekształcanie przestrzeni społecznej placówki. Studium społeczno-pedagogiczne na przykładzie żłobków, Łódź, Wydawnictwo Uniwersytetu Łódzkiego.

\section{Akty prawne}

Krajowy Standard Kompetencji Zawodowych, Wychowawca małego dziecka (234202), Ministerstwo Pracy i Polityki Społecznej, Warszawa 2013.

Rozporzq̨dzenie MPiPS z dnia 25 marca 2011 roku (Dz.U., nr 69, poz. 368).

Ustawa z dnia 4 lutego 2011 roku o opiece nad dziećmi w wieku do lat 3 (Dz.U. 2011, nr 45, poz. 235). 